\title{
Criminal Liability Against Maladministration by Civil Service Application in Land Procurement for Public Facilities
}

\author{
I Made Sepud \\ Faculty of Law \\ Universitas Warmadewa \\ Denpasar-Bali, Indonesia \\ sepudmade@gmail.com
}

\begin{abstract}
This paper examines the legal protection for the civil apparatus who committed maladministration in the process of land acquisition for the construction of public facilities and describes criminal liability to the state civil apparatus in the commission of maladministration in the land procurement for public facilities. This study belongs to normative law. Statute approach and conceptual approach to legislation were used in conducting analysis on the object of this study. The results show that legal protection for the administrative mistakes commission in the process of land acquisition for construction of public facilities by State Civil Apparatus can be granted by applying the principle of Legal Protection for the State Civil Apparatus in performing the duties namely through providing legal assistance in cases faced by courts in relation to the execution of their duties. Criminal liability for the State civil apparatus against maladministration in land acquisition for construction of public purposes may be determined from the element of maladministration carried out, which affects the state financial loss.
\end{abstract}

Keywords-criminal liability; civil state apparatus; maladministration

\section{INTRODUCTION}

In order to realize a fair and prosperous society based on Pancasila, the state ideology and the 1945 Constitution of the Republic of Indonesia, the government needs to conduct development. One of the efforts to organize development in a national development system that needs to be implemented by the government is the development for the public interest. Development for public interest must be carried out by the government to meet the needs of the people. Development for the public interest can be self-managed by the government and also by cooperating with State-Owned Enterprises, Regional Owned Enterprises, or Private Enterprises [1].

Development, especially physical development, absolutely requires land. The land needed can be a land controlled by the state or royal land, as well as existing land rights by a subject of law (land rights) [2]. If the land required for development is in the form of state land or the royal land (not land of property right), its acquisition is not difficult, that is by way of state or kingdom of the state may acquire the land for subsequent use for development. It is different if the land is a land of property, it will be complicated in the execution of its procurement [3]

Land acquisition for public interest is pursuant to Law Number 2 Year 2014 on Land Procurement for Development for the Public Interest [4], asserts that land procurement is used for development:

- Defense and national security;

- Public roads, toll roads, tunnels, railways, railway stations and railway operations facilities;

- Reservoirs, dams, irrigation, drinking water supply, drainage and sanitation, and other irrigation structures;

- Ports, airports and terminals;

- Oil, gas and geothermal infrastructure;

- Generators of transmission, substations, network and distribution of electric power;

- Telecommunication networks and government information;

- Sewage and waste treatment;

- Government hospital/local government;

- Public-safety facilities;

- Public burial place of government/local government;

- Social facilities, public facilities and open green public spaces;

- Nature reserve and cultural heritage;

- Offices of government/local government/village;

- Settlement of urban slums and/or for land consolidation, and housing for low-income communities with rental status;

- Education infrastructure or government/local government schools

- Government/local government sports infrastructure; and 
- Public market and public parking.

The provisions of Article 1 paragraph 2 of Law No. 2 of 2012 [5] on the procurement of land for development for public interest, land acquisition is the supply of land by providing decent and fair compensation to the party entitled, i.e. to the party that controls or has the object of land acquisition. Article 1 (6) of Law No. 2 of 2012 confirms that the notion of public interest is the interest of the nation, the state and society to be realized by the government and used for the greatest prosperity to the nation [6].

Procurement of land for the public benefit aims to provide land for the implementation of development to improve the welfare and prosperity of the nation, the state and the society by ensuring the legitimate interests of the entitled parties [7]. This is in line with the national land law which recognizes and respects the rights of the public on land and objects as well as giving public authority to the state under the form of authority to regulate, to conduct studies, to manage, and to supervise. Based on the Mandate of Law No. 2 of 2012, the state civilian apparatus set up as a government tool is assigned to carry out land procurement processes for development for the public interest, both from the planning process, preparation, execution and reporting of results. Some of the legal issues that hinder the state civilians in the process of land procurement for development for the public benefit are in the form of corruption or maladministration [8].

The existence of several legal cases in the land procurement process of land acquisition for the construction of public facilities is certainly very hard for civil servants of the state, where when they have done the task for the procurement of land for development for public facilities aimed at improving the prosperity of the nation, state and communities while ensuring the legal interests of the rightful parties, are at risk for them to be involved in legal cases that would sacrifice their status as the state's civil apparatus and the survival of their family. Of course, there are various checks on the land procurement process, whether conducted by regional inspectors, financial examination bodies, police and by the prosecutor's office. In the process of examination, it is often found there are errors committed by the civil apparatus of the country either in the form of procedures, maladministration and corruption.

Based on the description above, this paper aims at examining the legal protection for the State Civil Apparatus that commit violations in the process of land acquisition for the construction of public facilities and describing criminal liability for the State Civil Apparatus on the maladministration in the procurement of land through the construction of public facilities.

\section{METHOD}

This study belongs to normative investigation, exploring legal regulation of the protection and criminal liability against maladministration commission in the land procurement for public interest of development. I used statute approach and conceptual approach to legislation to explore the criminal liability of maladministration in the land procurement and to describe the legal protection for the Civil Apparatus in committing such mistakes. Library study was also used in collecting related literature to support the analysis. Qualitative descriptive was applied in making the sense of the data and in presenting the results.

\section{RESULT AND DISCUSSION}

\section{A. Legal Protection for the Commission of Maladministration in the Land Procurement for Development of Public Facilities}

In the field of land law, the problem that always arises from the past to the present, is the problem of community land owned or residents for the implementation of government projects for the public interest. Land acquisition issues involving land acquisition, land distribution, removal of land rights, or by any term, it will invariably involve the interests of the government and the people/landowner [9]. The two the government and community must both observe and comply governing laws regulations on the procurement of land for development for the public interests.

The consequence of the right of control by a State which is intended to be used for the greatest prosperity of the people is the State has the right or power to cancel or restore the rights to land owned or controlled by the people to provide appropriate compensation and according to the provisions in the Law. The revocation of land rights is possible whilst meeting the prescribed conditions, namely there should be appropriate compensation, or replaced with suitable land in terms of the value, benefits and abilities of replacement land, i.e., the land that is revoked for public interest through the process according to the provisions of legislation.

The provisions of Article 2 of Law Number 2 of 2012 on Land Procurement for Development for the Public Interest affirm that the procurement of land for public interest is implemented based on the principles:

- Humanity;

- Justice;

- Benefits;

- Certainty;

- Openness;

- Agreement;

- Participation;

- Welfare;

- Sustainability; and

- Harmony.

In the appraisal of compensation for the disposal of land rights at the location of the development plan of public facilities the land agency shall appoint the appraisal in accordance with the provisions of legislation that is in accordance with the provisions concerning the procurement of goods/services of government agencies. 


\section{B. Criminal Liability for the State Civil Apparatus in the Commission of Maladministration in the Land Procurement for Public Facilities}

The land agency announces a predetermined assessment for carrying out the assessment of land acquisition objects. The determined penalty must be responsible for the assessment that has been implemented. Violation of appellant liability shall be liable to administrative and/or criminal sanctions in accordance with the provisions of legislation.

Number 5 of Law Year 2014 on State Civil Apparatus adheres to the principle that the Legal Assurance Guarantee in carrying out official duties is the principle of the Professional State Civil Service that is affirmed in the provision of Article 3 letter $\mathrm{f}$ which states that the State Civil Apparatus as a profession is based on the principle of legal protection in carrying out duties [10]. The provisions of Article 106 SubArticle d of Law Number 5 of 2014 confirm that the government shall provide protection in the form of legal aid.

Legal assistance is provided by the government in the form of legal aid in legal cases in the courts related to the implementation of their duties. Furthermore, the provision of Article 106 paragraph (1) point e and paragraph (3) of Law Number 5 Year 2014 also affirms that the government is obliged to provide protection in the form of legal aid related to the execution of its duties.

The relationship between the central government and the local government is that they regulate the similar legal action against the State Civil Apparatus in the Local Government Agencies. The provisions of article 385 Paragraph (3) of Law Number 23 of 2014 confirms that the Law Enforcement Officer conducts an examination of allegations by State Civil Apparatus reported by the public after coordination with the government's internal supervisory apparatus or nongovernmental supervisory board [4].

Furthermore, the provision of paragraph (4) stipulates that if in the result of inspection as referred to in paragraph (3), evidence of administrative irregularities are discovered, further process shall be submitted to the Government Internal Supervisory Apparatus. Besides, the provision of paragraph (5) stipulates that if based on the result of inspection as referred to in paragraph (3), evidence of criminal deviation is found, the process is further submitted to law enforcement officers in accordance with the provisions of legislation.

The provision of Article 385 requires that any public reports relating to irregularities committed by the State Civil Apparatus shall be followed up by an internal supervisory officer or by law enforcement officers, and if such deviations are maladministration, the proceedings are further submitted to the government's internal control officers. However, if there are irregularities indicating a criminal deviation, the follow-up is brought to the law enforcement officers [11].

\section{CONCLUSION}

The legal protection for the State Civil Apparatus committing maladministration in the process of land acquisition for development for the public interest may be granted by applying the principle of Legal Protection for the
State Civil Apparatus in performing its duties by providing legal assistance in cases faced by courts in relation to the execution of their duties, allegations of irregularities perpetrated by the State Civil Apparatus which lead to criminal acts shall be brought to the law enforcement officers.

Criminal liability for civil state apparatuses against maladministration in the procurement of land for development for the public interest can be determined from the element of maladministration carried out, which affects the financial losses of the State. Maladministration committed in the form of behavior against the law exceeds the authority, misuse of authority for other purposes of the purpose of such authority, including negligence or neglect of legal obligations intentionally to cause losses of the State and meet the elements of corruption, the maladministration is the cause of action against the law of corruption so that it can be subject to criminal prosecution.

\section{ACKNOWLEDGEMENT}

The author would like to thank all the parties who have helped and contributed in the writing of this article, both those who contribute in the form of funding and critical ideas. Hopefully this paper can be useful theoretically and practically for the addition and development of knowledge, especially in the field of legal science.

\section{REFERENCES}

[1] Bakri M., Hak Menguasai Tanah Oleh Negara (Paradigma Baru Untuk Reformasi Agraria). Yogyakarta: Citra Media; 2017.

[2] Rubaie A., Hukum Pengadaan Tanayh Untuk Kepentingan Umum. Malang: Bayumedia Publishing; 2017. 39 p.

[3] Ratnaningsih M., Viktimasi Kejahatan di Bidang Pertanahan. Yogyakarta: Leksbang Presindo; 2006. 61 p.

[4] Law of the Republic of Indonesia Number 23 of 2014 on Regional Government, State Gazette of the Republic of Indonesia of 2014 Number 244. Supplement to State Gazette of the Republic of Indonesia Number 5587;

[5] Law of the Republic of Indonesia Number 2 of 2012 on Land Procurement for Development for the Interest Uumum, Gazette of the Republic of Indonesia Year 2012 Number 22. Supplement to the State Gazette of the Republic of Indonesia Number 5280;

[6] Law of the Republic of Indonesia Number 20 of 2001 on the Amendment of the Law of the Republic of Indonesia Number 31 of 1999 on Corruption, the State Gazette of the Republic of Indonesia Year 2001 Number 134. Supplement to the State Gazette of the Republic of Indonesia Number 4150;

[7] Law of the Republic of Indonesia Number 20 of 1961 concerning the Revocation of Land and Property Rights Above, State Gazette of the Republic of Indonesia of 1961 Number 228. Supplement to the State Gazette of the Republic of Indonesia Number 2324;

[8] Law of the Republic of Indonesia Number 31 of 1999 regarding Corruption Crime, 1999 State Gazette of the Republic of Indonesia Number 140. Supplement to State Gazette Number 3874;

[9] Law of the Republic of Indonesia Number 5 of 1960 on Basic Regulation of Agrarian Principles, 1960 State Gazette of the Republic of Indonesia Number 104. Supplement to State Gazette of the Republic of Indonesia Number 2043;

[10] Law of the Republic of Indonesia Number 30 of 2014 on Government Administration, the State Gazette of the Republic of Indonesia of 2014 
Number 244. Supplement to the State Gazette of the Republic of Indonesia Number 5587;

[11] Presidential Regulation No. 71/2012 concerning Implementation of Land Procurement for Development in the Public Interest. State Gazette of the Republic of Indonesia of 2012 Number 156; 